\title{
ANALISIS HUKUM TENTANG PERBUATAN MELAWAN HUKUM DALAM TRANSAKSI BISNIS SECARA ONLINE (E-COMMERCE) BERDASARKAN BURGERLIJKE WETBOEK DAN UNDANG- UNDANG NOMOR 11 TAHUN 2008 TENTANG INFORMASI DAN TRANSAKSI ELEKTRONIK
}

\author{
Hetty Hassanah \\ Fakultas Hukum Universitas Komputer Indonesia \\ E-mail: het_rara@yahoo.co.id
}

\begin{abstract}
The usage of internet in humans activities causes a borderless world circumstance. There are a lot of people all over the world can take adventages of internet for their daily lives, but there are also some disadventages or bad impacts of internet itself,especially in online business activities, as it is wellkown as E-Commerce. In practice, E-Commerce activity is very close related to an agreement which has been regulated in Civil Law, and the implementation or application of this activity often causes disadventages or loses for other parties. This is what we call deed against the law. This deed against the law conventionally has been regulated inBurgerlijke Wetboek (BW), article 1365, but it is not explicitly regulated in Act No. 11 year 2008, wheras one of the provision which can be applied in E-Commerce in Indonesia isAct No. 11 year 2008. Such condition makes more disadventages or loses caused by deed against the law in online business activity, but so far Act No. 11 year 2008 has not accomodate these problems.
\end{abstract}

Keywords: e-commerce; deed against the law; online business transaction.

\begin{abstract}
Abstrak
Pemanfaatan internet dalam aktivitas manusia menyebabkan keadaan dunia yang tanpa batas (borderless). Banyak kegunaan internet yang dapat dinikmati manusia dalam kehidupannya sehari-hari, namun adanya internet pun tidak luput dari berbagai masalah yang ditimbulkannya. Begitu pula dalam kegiatan bisnis, yang dapat dilakukan secara online atau dikenal dengan istilah E-Commerce. Pada praktiknya aktivitas E-Commerce ini berkaitan dengan perjanjian yang diatur dalam hukum perdata, dan pelaksanaannya seringkali menimbulkan masalah yang menyebabkan kerugian bagi pihak lainnya. Perbuatan yang timbul dan menimbulkan kerugian seperti itu disebut perbuatan melawan hukum. Perbuatan ini secara konvensional telah diatur dalam Pasal 1365 Burgerlijke Wetboek (BW), namun tidak diatur secara eksplisit dalam Undang-Undang Nomor 11 Tahun 2008, padahal salah satu ketentuan hukum yang dapat diterapkan dalam E-Commerce di Indonesia adalah undang-undang temaksud. Kondisi ini menyebabkan banyak terjadi kerugian yang diakibatkan perbuatan melawan hukum tersebut dalam transaksi bisnis secara online, namun Undang-Undang Nomor 11 Tahun 2008 belum dapat mengakomodir masalah tersebut.
\end{abstract}

Kata Kunci: E-Commerce, Perbuatan Melawan Hukum. 


\section{A. PENDAHULUAN}

Indonesiasaatinisedangmelaksanakan pembangunan nasional di berbagai bidang dengan beberapa target peningkatan hasil-hasil pembangunan tersebut bagi kesejahteraan masyarakat. Diantara sekian banyak sektor pembangunan nasional, pembangunan di bidang perekonomian merupakan salah satu agenda yang sangat penting dan sangat berpengaruh langsung terhadap kehidupan masyarakat di Indonesia. Perdagangan merupakan salah satu bidang yang menunjang kegiatan ekonomi dalam masyarakat, di samping itu juga turut mempengaruhi kondisi perekonomian nasional. Peranan perdagangan sangat penting dalam meningkatkan pertumbuhan ekonomi secara berkesinambungan, meningkatkan pelaksanaan pembangunan nasional guna mewujudkan pemerataan pembangunan berikut hasil-hasilnya serta memelihara kemantapan stabilitas nasional. Salah satu upaya yang dapat dilakukan guna merealisasikan pertumbuhan ekonomi secara signifikan di sektor perdagangan, khususnya di era globalisasi adalah melalui proses penerapan antara sistem perdagangan dengan teknologi informasi. ${ }^{1}$

Saat ini pengembangan dan penerapan teknologi informasi di sektor ekonomi telah berkembang dengan cepat. Pengembangan dan penerapan teknologi informasi yang demikian cepat telah mengakibatkan semakin mudahnya arus informasi yang dapat diperoleh masyarakat, sekaligus memudahkan orang untuk melakukan komunikasi satu sama lain dengan melintas batas ruang dan waktu. Globalisasi dalam dunia ekonomi, khususnya perdagangan, semakin dimudahkan dengan adanya internet (Interconnected Networking) sebagai media komunikasi yang cepat.

Transaksi perdagangan dapat dilakukan secara langsung maupun secara tidak langsung, dalam arti melalui media internet (dunia maya/cyber space). Transaksi perdagangan dengan memanfaatkan sarana internet telah mengubah dunia bisnis dari pola perdagangan tradisional menjadi sistem perdagangan yang lebih modern, yaitu sistem perdagangan secara virtual dan dikenal denganistilahElectronic Commerce. Pada perkembangannya Electronic Commerce (E-Commerce) lahir selain disebabkan oleh adanya perkembangan teknologi informasi, juga karena tuntutan masyarakat terhadap pelayanan yang serba cepat, mudah, praktis, dan menghendaki kualitas yang lebih baik.

Transaksi perdagangan secara elektronik di Indonesia menunjukkan perkembangan yang pesat, dalam hal ini teknologi internet khususnya e-commerce memiliki pengaruh yang sangat besar terhadap perdagangan global. Perkembangan yang sangat pesat dari Electronic Commerce (e-commerce) ini disebabkan oleh beberapa hal, sebagai berikut: $^{2}$

1. Electronic Commerce memiliki kemampuan untuk menjangkau lebih banyak pelanggan dan setiap saat pelanggan dapat mengakses seluruh informasi secara terus-menerus; 
2. Electronic Commerce dapat mendorong kreatifitas dari pihak penjual secara tepat dan cepat serta pendistribusian informasi yang disampaikan berlangsung secara periodik;

3. Electronic Commerce dapat menciptakan efisiensi yang tinggi, murah, dan informatif;

4. Electronic Commerce dapat meningkatkan kepuasan pelanggan, dengan pelayanan yang cepat, mudah, aman, dan akurat;

Transaksi perdagangan melalui internet sangat menguntungkan banyak pihak, sehingga transaksi perdagangan ini sangat diminati, tidak saja bagi produsen tetapi juga konsumen. Secara umum, Electronic Commerce telah memberi manfaat tersendiri baik bagi konsumen maupun bagi produsen. Bagi konsumen Electronic Commerce mengubah cara konsumen dalam memperoleh produk yang diinginkan, sedangkan bagi produsen, Electronic Commerce telah mempermudah proses pemasaran suatu produk.

Meskipun penggunaan internet dalam transaksi perdagangan menjanjikan berbagai kemudahan, namun hal ini tidak berarti Electronic Commerce merupakan suatu sistem yang terbebas dari masalah, khususnya bagi negara yang belum mengatur mengenai Electronic Commerce. Pada praktiknya telah banyak kasus-kasus yang merugikan konsumen sebagai akibat dari penggunaan media internet dalam transaksi perdagangan ini ${ }^{3}$. Kasus tersebut misalnya adanya tindakan wanprestasi dari pelaku usaha terhadap konsumennya dalam suatu transaksi jual beli melalui internet, dalam hal ini konsumen telah melakukan pembayaran melalui fasilitas internet banking kepada pelaku usaha, namun pelaku usaha tidak mengirimkan barang yang telah dibeli konsumen atau pelaku usaha keliru dalam mengirimkan barang tersebut, sehingga hal ini merugikan konsumen. Selain itu sering pula terjadi perbuatan-perbuatan yang dapat dikualifikasikan sebagai perbuatan melawan hukum.

Saat ini di Indonesia telah ada UndangUndang Nomor 11 Tahun 2008 Tentang Informasi Dan Transaksi Elektronik (selanjutnya disebut Undang-Undang ITE). Pada Undang-Undang ITE tersebut telah ada pengaturan mengenai transaksi elektronik termasuk perdagangan melalui internet, namun seringkali tidak dapat mengakomodir kasus perbuatan melawan hukum dalam transaksi elektronik tersebut dikarenakan luasnya cakupan pengertian perbuatan melawan hukum yang tidak diatur secara eksplisit atau secara khusus dalam Undang-Undang ITE tersebut. Pengaturan tentang perbuatan melawan hukum hanya diatur dalam Pasal 1365 BW, yang memerlukan penafsiran hukum dalam menerapkan ketentuan tersebut terhadap kasus-kasus perbuatan melawan hukum dalam E-commerce. Terlebih lagi seringkali perbuatan melawan hukum langsung dianggap sebagai sebuah perbuatan pidana, sehingga menimbulkan kesulitan dalam menuntut kerugian materil dan immaterial, karena sanksi pidana hanya memberikan hukuman badan dan atau denda yang tujuannya menimbulkan efek jera kepada pelaku.

3 M. Arsyad Sanusi, Transaksi Bisnis dalam Electronic Commerce, Jurnal Hukum, Nomor 16 Vol. 8, 2001. 


\section{B. PEMBAHASAN}

\section{Tinjauan Hukum Tentang Transaksi} Bisnis Secara Online (E-Commerce)

Perkembangan ilmu pengetahuan dan teknologi memberikan pengaruh yang sangat luas terhadap setiap bidang kehidupan, termasuk pada proses transaksi perdagangan atau jual beli. Pada kenyataan yang terjadi di masyarakat telah banyak dilakukan proses transaksi perdagangan melalui media elektronik yang dikenal dengan istilah E-Commerce, yang mana pihak-pihak yang hendak melakukan transaksi tidak harus bertatap muka, namun dapat dilakukan dalam kondisi masing-masing pihak berada di tempat yang berbeda. Transaksi seperti ini dilakukan melalui suatu sistem yaitu internet, dan hal tersebut bukan merupakan sesuatu yang baru dalam masyarakat, termasuk di Indonesia.

Berbicara mengenai keabsahan suatu transaksi secara elektronik, maka pertama-tama harus ditegaskan terlebih dahulu dasar hukum dari transaksi termaksud. Transaksi secara elektronik lahir berdasarkan asas kebebasan berkontrak sebagaimana telah diatur dalam Pasal 1338 ayat (1) BW, yang mana setiap orang bebas untuk menentukan bentuk, macam dan isi perjanjian/ perikatan asalkan tetap memenuhi syaratsyarat sahnya perjanjian sesuai ketentuan Pasal 1320 BW, tidak melanggar ketertiban umum dan kesusilaan, sehingga setiap perjanjian yang dibuat oleh para pihak menjadi undang-undang bagi pihakpihak yang membuatnya. Begitu pula dalam transaksi secara elektronik, pihak- pihak yang terlibat dalam transaksi itu merupakan subjek hukum, baik orang maupun badan hukum bebas melakukan perikatan dengan bentuk, cara serta isi yang ditentukan berdasarkan kesepakatan pihak-pihak tersebut, dalam hal ini para pihak melakukan perikatan berupa transaksi melalui media internet dengan isi perjanjian yang disepakati para pihak melalui internet pula, jadi mereka saling berhubungan melalui media internet.

Menurut ketentuan Pasal 1320 BW, syarat sahnya suatu perjanjian terdiri dari:

a. Kesepakatan para pihak

b. Kecakapan para pihak

c. Suatu hal tertentu

d. Suatu sebab yang halal

Kesepakatan para pihak maksudnya harus ada persesuaian kehendak antara para pihak yang membuat perjanjian baik diungkapkan secara tegas maupun diam-diam. Apabila kesepakatan timbul karena adanya paksaan, kekhilafan atau kekeliruan maka perjanjian dapat dibatalkan artinya perjanjian masih berlaku sampai dibatalkan oleh hakim atas permintaan para pihak, dengan demikian kesepakatan ini merupakan salah satu syarat subjektif untuk sahnya perjanjian. Demikian pula dalam transaksi secara elektronik, perjanjian terjadi setelah ada kesepakatan dari para pihak yang mengadakan transaksi tersebut. Berdasarkan asas konsensualisme perjanjian dianggap ada bersamaan dengan timbulnya kesepakatan untuk melakukan suatu perikatan. Terdapat beberapa teori mengenai kesepakatan yaitu: ${ }^{4}$

4 Riduan Syahrani, Seluk-Beluk Dan Asas-Asas Hukum Perdata, Alumni, Bandung, 1992, hlm. 214. 
a. Uitings theorie (teori saat melahirkan kemauan), menurut teori ini perjanjian terjadi apabila atas penawaran telah dilahirkan kemauan dari pihak lain dan kemauan ini dikatakan ada pada waktu pihak lain mulai menulis surat penerimaan, (Expedition Theory);

b. Verzend theorie (teori saat mengirim surat penerimaan), menurut teori ini perjanjian terjadi pada saat surat penerimaan dikirimkan kepada Penawar, (Transmission Theory);

c. Onvangs theorie (teori saat menerima surat penawaran), menurut teori ini perjanjian terjadi pada saat surat penerimaan sampai di alamat Penawar, (Reception Theory);

d. Vernemings theorie (teori saat mengetahui surat penerimaan), menurut teori ini perjanjian baru terjadi apabila Penawar telah membuka dan membaca surat penerimaan, (Information Theory).

Sementara itu, Viena Convention on International Sales of Goods (1988) telah menerima Reception Theory. Berdasarkan Pasal 15 The Uncitral Model Law on E-Commerce (1996), dikatakan bahwa tempat sahnya data message dikirim atau diterima, kecuali diatur berlainan, dalam hal ini pengiriman berita berlangsung pada tempat di mana pengirim berita memiliki tempat usahanya yang sah (place of business) dan diterima pada tempat di mana penerima berita memiliki tempat usahanya yang sah. Penunjukan pada Uncitral Model Law 1996 ini dilakukan mengingat pada dasarnya pertukaran data elektronik (elektronic data interchange) mengikuti metode pertukaran data bisnis atau perdagangan standar dengan format yang lazim disepakati oleh para pihak.

Kecakapan para pihak merupakan syarat umum untuk dapat melakukan perbuatan hukum yang sah. Seseorang dikatakan cakap hukum (rechtsbekwaamheid) apabilatelahdewasa, sehat akal pikiran dan tidak dilarang oleh peraturan perundang-undangan. Dewasa menurut Pasal 47 Undang-Undang Nomor 1 Tahun 1974 Tentang Perkawinan adalah telah berusia 18 tahun atau telah menikah. Sehat akal pikiran artinya tidak cacad mental, bukan pemboros dan tidak berada di bawah pengampuan sesuai Pasal 1330 jo 433 BW. Apabila syarat kecakapan yang juga merupakan syarat subjektif ini tidak terpenuhi dalam suatu perjanjian maka perjanjian dapat dibatalkan sebagaimana telah dijelaskan pada bagian sebelumnya. Seseorang yang cakap hukum (rechtsbekwaamheid) belum tentu berwenang untuk melakukan perbuatan hukum (rechtsbevoegheid), dengan demikian rechtsbekwaamheid merupakan syarat umum dalam melakukan perbuatan hukum sedangkan rechtsbevoegheid merupakan syarat khususnya. Begitu pula dalam suatu transaksi secara elektronik, para pihak yang terkait harus memenuhi syarat kecakapan ini, namun pada kenyataannya pihak yang satu tidak mengetahui apakah pihak lainnya memenuhi syarat kecakapan atau tidak, tetapi dalam transaksi secara elektronik ini harus didasari dengan unsur kepercayaan satu sama lain.

Suatu hal tertentu dalam perjanjian maksudnya adalah barang yang menjadi objek suatu perjanjian yaitu barang yang dapat diperdagangkan sebagaimana diatur dalam Pasal 1332 BW. Menurut 
Pasal 1333 BW, barang yang menjadi objek suatu perjanjian harus tertentu atau setidak-tidaknya harus ditentukan jenisnya, sedangkan jumlahnya tidak perlu ditentukan asalkan saja kemudian dapat ditentukan atau diperhitungkan. Pasal 1334 ayat (1) BW menentukan bahwa barang-barang yang baru akan ada di kemudian hari juga dapat menjadi objek perjanjian, sedangkan dalam Pasal 1334 ayat (2) BW disebutkan bahwa barangbarang yang akan masuk hak warisan seseorang dari seorang lain sebagai pewaris tidak dapat dijadikan objek suatu perjanjian karena dianggap melanggar kesusilaan kecuali apabila sebelumnya barang tersebut telah dihibahkan oleh calon pewaris kepada calon ahli warisnya. Perjanjian yang objeknya melanggar ketentuan-ketentuan tersebut di atas, sebagai syarat objektif untuk sahnya perjanjian maka perjanjian batal demi hukum artinya sejak semula perjanjian dianggap tidak pernah ada sehingga tidak ada dasar untuk saling menuntut di muka hakim (pengadilan). Pada transaksi secara elektronik, objek yang diperjanjikan harus jelas, baik jenis maupun jumlahnya.

Suatu sebab yang halal merupakan syarat objektif lain untuk sahnya perjanjian. Berdasarkan Pasal 1335 BW suatu perjanjian tanpa sebab atau yang telah dibuat karena suatu sebab yang palsu atau terlarang, tidak mempunyai kekuatan.

Selain asas kebebasan berkontrak, hukum perjanjian yang berlaku di Indonesia mengenal beberapa asas lain yaitu: ${ }^{5}$ a. Asas konsensualisme, yaitu menganggap bahwa perjanjian telah ada sejenak setelah ada kata sepakat dari para pihak.

b. Asas kepercayaan, antara para pihak untuk saling mengikatkan diri masing-masing dalam melaksanakan perjanjian.

c. Asas kekuatan mengikat, maksudnya bahwa para pihak tidak hanya terikat pada isi perjanjian tetapi juga terhadap asas moral, kepatutan dan kebiasaan.

d. Asas persamaan hukum, artinya kedua pihak sama kedudukannya di depan hukum sehingga harus saling menghormati satu sama lain.

e. Asas keseimbangan, maksudnya bahwa para pihak wajib melaksanakan kewajibannya masing-masing dengan itikad baik.

f. Asas kepastian hukum, hal ini dapat terlihat dari ketentuan bahwa perjanjian yang dibuat para pihak berlaku sebagai undang-undang bagi para pembuatnya.

g. Asas Moral, maksudnya dalam melaksanakan perjanjian ada motivasi berdasarkan moral sebagai panggilan hati nuraninya.

h. Asas kepatutan, yang dituangkan dalam Pasal 1339 BW bahwa isi perjanjian tidak bertentangan dengan peraturan perundang-undangan yang berlaku, kepatutan dan kesusilaan.

i. Asas kebiasaan, diatur dalam Pasal 1339 jo 1347 BW, maksudnya bahwa suatu perjanjian tidak hanya menyangkut hal-hal yang telah diatur dalam peraturan perundang-

5 Wirjono Prodjodikoro, Asas-Asas Hukum Perjanjian, Cet. VIII, Sumur Bandung, Jakarta, 1985, hlm. 35. 
undangan tetapi juga menyangkut kebiasaan yang lazim diikuti.

Dengan demikian transaksi yang dilakukan secara elektronik pun terikat pada asas-asas sebagaimana telah dijelaskan di atas.

Selain syarat sahnya perjanjian sebagaimana telah dijelaskan di atas, kita juga harus mengetahui unsur-unsur perjanjian menurut ilmu hukum perdata yaitu: 6

a. Unsur essentialia, yaitu unsur-unsur pokok yang mutlak harus ada dalam suatu perjanjian, seperti identitas para pihak, kesepakatan dalam perjanjian.

b. Unsur naturalia, yaitu unsur-unsur yang dianggap telah ada dalam perjanjian sekalipun para pihak tidak menentukan secara tegas dalam perjanjian, seperti itikad baik dalam perjanjian, tidak ada cacad tersembunyi dalam objek perjanjian.

c. Unsur accedentialia, yaitu unsurunsur yang ditambahkan ke dalam perjanjian oleh para pihak, seperti klausul "barang yang sudah dibeli tidak dapat dikembalikan".

Unsur-unsur tersebut di atas harus diterapkan pula dalam suatu transaksi secara elektronik, artinya identitas para pihak harus jelas begitu juga dengan kesepakatan tidak boleh terjadi cacat hukum artinya tidak boleh ada unsur paksaan, kekhilapan dan penipuan. Transaksi yang dilakukan secara elektronik harus disertai dengan itikad baik dan rasa kepercayaan antara para pihak, walaupun hal ini tidak ditegaskan dalam perjanjiannya. Pada setiap transaksi termasuk yang dilakukan melalui eletronik dapat ditentukan klausula ekseronasi sebagai bagian dari unsur accedentialia sebagaimana diuraikan di atas.

Berdasarkan perkembangan teknologi informasitransaksibisnistidakhanyadapat dilakukan secara nyata atau konvensional, tetapi juga melalui media elektronik dalam hal ini internet, yang selanjutnya dikenal dengan istilah e-commerce. Berdasarkan ketentuan Pasal 1 angka (2) UndangUndang Nomor 11 Tahun 2008 Tentang Informasi Dan Transaksi Elektronik (selanjutnya disebut Undang-Undang ITE), dinyatakan bahwa transaksi elektronik adalah perbuatan hukum yang dilakukan dengan menggunakan komputer, jaringan komputer dan/atau media elektronik lainnya. Sejalan dengan hal tersebut, suatu transaksi elektronik termasuk transaksi perdagangan secara elektronik harus dituangkan ke dalam sebuah kontrak elektronik yang mengikat para pihak, sesuai ketentuan Pasal 18 Undang-Undang ITE.

Transaksi bisnis secara elektronik (electronic commerce/e-commerce), sebagai bagian dari electronic business (bisnis yang dilakukan dengan menggunakan electronic transmission), dapat dirumuskan definisinya berdasarkan terminology perniagaan secara elektronik (e-commerce). Secara umum e-commerce dapat didefinisikan sebagai segala bentuk transaksi perdagangan barang atau jasa (trade of goods and service) dengan menggunakan media elektronik. Selain yang telah disebutkan di atas, bahwa kegiatan perniagaan tersebut merupakan

$6 \quad$ R. Subekti, Aneka Perjanjian, Cet. VII, Alumni, Bandung, 1985, hlm. 30. 
bagian dari kegiatan bisnis (e-commerce is apart of e-business).

Transaksi e-commerce melibatkan beberapa pihak, baik yang terlibat secara langsung maupun tidak langsung, diantaranya: ${ }^{7}$
a. Penjual (merchant)
b. Konsumen atau card holder.
c. Bank
d. Provider
e. Certification Authorities

Rayport dan Jaworski berpendapat bahwa ada 4 (empat) kategori aplikasi e-commerce, yaitu: ${ }^{8}$

a. Business to Business (perusahaan ke perusahaan)

Aplikasi e-commerce Business to Business merujuk pada spektrum penuh e-commerce yang terjadi antara dua perusahaan. E-commerce Business to Business ini meliputi aktifitasaktifitas seperti pembeli dan penjual, suplier management, inventory management, channel management, payment management, serta service dan suport, e-commerce Business to Business ini antara lain dipelopori oleh Chemdex (www.chemdex.com), FastParts (www.fastparts.com) dan FreeMarkets (www.freemarkets.com).

b. Business to Consumer (perusahaan ke konsumen)

E-commerce Business to Consumer merujuk pada pertukaran yang terjadi antara perusahaan dengan konsumen. Pelopor-pelopor kategori e-commerce business to consumer ini antara lain adalah Amazon.com, Yahoo.com dan Schwab.com. Transaksi-transaksi yang sama seperti yang terjadi dalam konteks e-commerce Business to Consumer juga terjadi dalam e-commerce business to consumer ini. Transaksi-transaksi tersebut antara lain meliputi: aktifitas penjualan, pencarian konsumen serta pelayanan dan dukungan (service and support) bagi para konsumen.

c. Consumer to Consumer (konsumen ke konsumen)

Pertukaran Consumer to Consumer ini mencakup transaksi-transaksi yang terjadi antara dan diantara konsumen dengan konsumen. Pertukaran tersebut bisa melibatkan atau tidak melibatkan pihak ketiga, seperti yang terjadi dalam pertukaran lelang melalui situs eBay.

d. Consumer to business (konsumen ke perusahaan)

Dalam hubungan consumer to business ini konsumen-konsumen dapat mengikat diri bersama-sama untuk membentuk dan menjadikan diri mereka sebagai kelompok pembeli untuk suatu perusahaan. Dalam melakukan aktifitas-aktifitasnya tersebut para konsumen itu bisa didorong oleh orientasi ekonomi atau oleh orientasi sosial.

Transaksi bisnis secara online (e-commerce) harus dituangkan ke dalam suatu bentuk kontrak elektronik sebagai perwujudan dari asas kebebasan

\footnotetext{
7 Dikdik M. Arief Mansur dan Elisatris Gultom, Cyber Law Aspek Hukum Teknologi Informasi, PT Refika Aditama, Bandung: Mei 2005, hlm. 152-153.

8 Jeffrey F. Rayport dan Bernard J. Jaworski, E-commerce, McGraw-Hill/Irwin, Singapura, 2001, hlm. 3-4.
} 
berkontrak sebagaimana diatur dalam Pasal 1338 ayat (1) BW, dalam hal ini setiap orang memiliki kebebasan untuk membuat serta menentukan bentuk, macam dan isi perjanjian, asalkan tetap memenuhi syarat sahnya perjanjian sebagaimana telah diatur dalam Pasal 1320 BW, tidak melanggar ketertiban umum dan kesusilaan. Kontrak seperti itu mengikat dan berlaku sebagai undang-undang bagi para pihak pembuatnya. Menurut Pasal 1 angka (17) Undang-Undang ITE, kontrak elektronik adalah perjanjian para pihak yang dibuat melalui sistem elektronik. Sementara itu, berdasarkan Pasal 1 angka (5) Undang-Undang ITE, disebutkan bahwa sistem elektronik merupakan serangkaian perangkat dan prosedur elektronikyang berfungsi mempersiapkan, mengumpulkan, mengolah, menganalisis, menyimpan, menampilkan, mengumumkan, mengirimkan dan/atau menyebarkan informasi elektronik, dalam hal ini internet.

Pada Pasal 1 angka (1) UndangUndang ITE dijelaskan bahwa informasi elektronik adalah satu atau sekumpulan data elektronik termasuk tapi tidak terbatas pada tulisan, suara, gambar, peta, rancangan, foto, electronic data interchange, surat elektronik (electronic mail), telegram, teleks, telecopy atau sejenisnya, huruf, tanda, angka, kode akases, simbol atau perforasi yang telah diolah yang memiliki arti atau dapat dipahami oleh orang yang mampu memahaminya. Melihat hal di atas, tentu saja instrument yang digunakan dan berlaku dalam kontrak bisnis secara online ini merupakan hal-hal yang bersifat paperless, namun tetap diakui keabsahannya dan memiliki kekuatan hukum yang sama dengan kontrak secara konvensional. Oleh karena itu segala tindakan dan perbuatan hukum yang terjadi dalam kontrak bisnis secara online ini harus diperhatikan karena akibat hukum yang timbul memiliki dampak hukum yang sama dengan perbuatan hukum secara konvensional atau dalam dunia nyata.

Transaksi bisnis secara elektronik, melibatkan instrument dan perbuatan hukum di dunia maya dan bersifat paperless ini, melahirkan sistem pembuktian yang bersifat elektronik pula. Secara umum pembuktian yang berlaku dalam transaksi bisnis secara online yang didasarkan pada kontrak secara elektronik ini mengacu pada hukum pembuktian sebagaimana diatur dalam Pasal 1865 dan Pasal 1866 BW, yang menegaskan prinsip pembuktian bahwa setiap orang yang merasa memiliki hak atau merasa haknya terganggu, maka harus dapat membuktikannya secara hukum. Pembuktian yang dimaksud, harus mengikuti ketentuan alat bukti yang diakui secara hukum sebagaimana ditegaskan dalam Pasal 1866 juncto Pasal 164 HIR (Het Herziene Indonesisch Reglement), yang terdiri dari:
a. Bukti surat/tertulis;
b. Bukti saksi;
c. Bukti persangkaan;
d. Bukti pengakuan; dan
e. Bukti sumpah.

Semua alat bukti tersebut menjadi alat bukti dalam proses pembuktian perkara perdata termasuk yang berhubungan dengan kontrak atau perjanjian. Berdasarkan ketentuan Pasal 1865 BW di atas, pihak yang merasa memiliki hak atau 
merasa haknya secara perdata terganggu, maka harus dapat membuktikannya, dengan cara dan metode pembuktian yang telah ditentukan dalam hukum acara perdata. Namun demikian tidak berarti pihak lainnya tidak memiliki hak untuk melakukan pembuktian pula, artinya masing-masing pihak memiliki hak yang sama dalam proses pembuktian. Urutan alat bukti yang dapat diajukan adalah sebagaimana telah disebutkan dalam Pasal 1866 juncto Pasal 164 HIR di atas, secara mutatis mutandis.

Ada beberapa prinsip pembuktian yang harus diperhatikan antara lain:

a. Asas pembuktian dilakukan secara seimbang antara para pihak yang bersengketa;

b. Asas testimonium de auditu artinya bahwa bukti saksi dalam proses pembuktian adalah segala sesuatu yang dilihat, didengar dan dialami sendiri oleh saksi dan bukan keterangan orang lain;

c. Asas satu saksi bukan saksi, artinya bahwa alat bukti saksi harus didukung dengan alat bukti saksi lainnya sesuai peraturan perundangan yang berlaku dalam hukum acara perdata.

Melihat ketentuan di atas, proses pembuktian merupakan bagian penting yang harus diperhatikan dalam sebuah perjanjian atau kontrak termasuk kontrak bisnis secara online (E-Commerce). Menurut Pasal 5 ayat (1) UndangUndang ITE, informasi elektronik dan/ atau dokumen elektronik dan/atau hasil cetaknya merupakan alat bukti yang sah. Maksudnya bahwa informasi elektroniik dan/atau dokumen elektronik dan/atau hasil cetaknya dianggap sama dengan bukti tertulis sebagaimana ditentukan dalam urutan alat bukti yang diatur dalam Pasal 1866 BW juncto Pasal 164 HIR. Selanjutnya dalam Pasal 5 ayat (2) Undang-Undang ITE disebutkan pula bahwa informasi elektronik dan/atau dokumen elektronik dan/atau hasil cetaknya merupakan perluasan alat bukti yang sah sesuai dengan hukum acara yang berlaku di Indonesia. Kata "Perluasan" tersebut berarti Undang-Undang ITE telah memberikan ruang lebih luas dari alat bukti secara konvensional sehingga tidak ada kekosongan hukum dalam pembuktian segala aktivitas secara elektronik termasuk transaksi bisnis secara online. Hukum acara yang dimaksud adalah hukum acara perdata, pidana atau peradilan lain yang berlaku di Indonesia. Namun demikian, informasi elektronik dan/atau dokumen elektronik dan/atau hasil cetaknya ini dianggap sah apabila tidak melanggar ketentuan dalam Undang-Undang ITE, dan dalam beberapa keadaan informasi elektronik dan/atau dokumen elektronik dan/atau hasil cetaknya tersebut tidak berlaku untuk surat yang menurut undangundang harus dibuat dalam bentuk tertulis, juga dokumen yang menurut undang-undang harus dibuat dalam bentuk akta notaril atau akta yang dibuat oleh Pejabat Pembuat Akta, sebagaimana ditegaskan dalam Pasal 5 ayat (4) UndangUndang ITE. Dengan demikian berbicara mengenai transaksi bisnis secara online tidak terlepas dari ketentuan Buku III BW dan Undang-Undang ITE termaksud. 


\section{Perbuatan Melawan Hukum Berdasarkan Hukum Perdata di Indonesia}

Perbuatan melawan hukum (onrechtmatigedaad) diatur dalam Pasal 1365 KUH Perdata yang berbunyi:

"Tiap perbuatan melanggar hukum yang membawa kerugian kepada seorang lain, mewajibkan orang yang karena salahnya menerbitkan kerugian itu, mengganti kerugian tersebut".

\section{Seseorang yang dianggap telah} melakukan perbuatan melawan hukum dapat dikenakan sanksi dengan mengganti kerugian yang diderita korban akibat kesalahannya itu, melalui tuntutan yang diajukan kepada lembaga peradilan ataupun lembaga penyelesaian sengketa di luar pengadilan. Namun demikian harus dapat dibuktikan dan dipertanggungjawabkan kebenaran adanya perbuatan melawan hukum termaksud melalui pembuktian unsurunsur dari perbuatan melawan hukum ini, yang terdiri dari: ${ }^{9}$
a. Adanya perbuatan melawan hukum
b. Adanya kesalahan
c. Adanya Kerugian
d. Adanya hubungan sebab akibat antara perbuatan melawan hukum, kesalahan dan kerugian yang ada

Perbuatan melawan hukum dianggap terjadi dengan melihat adanya perbuatan dari pelaku yang diperkirakan memang melanggar undang-undang, bertentangan dengan hak orang lain, beretentangan dengan kewajiban hukum pelaku, bertentangan dengan kesusilaan dan ketertiban umum, atau bertentangan dengan kepatutan dalam masyarakat baik terhadap diri sendiri maupun orang lain, namun demikian suatu perbuatan yang dianggap sebagai perbuatan melawan hukum ini tetap harus dapat dipertanggungjawabkan apakah mengandung unsur kesalahan atau tidak. Pasal 1365 KUH Perdata tidak membedakan kesalahan dalam bentuk kesengajaan (opzet-dolus) dan kesalahan dalam bentuk kurang hati-hati (culpa), dengan demikian hakim harus dapat menilai dan mempertimbangkan berat ringannya kesalahan yang dilakukan sesorang dalam hubungannnya dengan perbuatan melawan hukum ini, sehingga dapat ditentukan ganti kerugian yang seadil-adilnya. ${ }^{10}$

Seseorang tidak dapat dituntut telah melakukan perbuatan melawan hukum, apabila perbuatan tersebut dilakukan dalam keadaan darurat/noodweer, overmacht, realisasi hak pribadi, karena perintah kepegawaian atau salah sangka yang dapat dimaafkan. Apabila unsur kesalahan dalam suatu perbuatan dapat dibuktikan maka ia bertanggung jawab atas kerugian yang disebabkan perbuatannya tersebut, namun seseorang tidak hanya bertanggungjawab atas kerugian yang disebabkan kesalahannnya sendiri, tetapi juga karena perbuatan yang mengandung kesalahan yang dilakukan oleh orangorang yang menjadi tanggungannya, barang-barang yang berada di bawah

9 Wirjono Prodjodikoro, Perbuatan Melanggar Hukum, Cet. V, Sumur Bandung, Bandung, 1967, hlm. 16.

10 Subekti, Pokok-Pokok Hukum Perdata, Intermasa, Jakarta, 1979, hlm. 56. 
pengawasannya serta binatang-binatang peliharaannya, sebagaimana ditentukan dalam Pasal 1366 sampai dengan Pasal 1369 KUH Perdata.

Berbicara tentang ganti rugi telah diatur dalam BW. Ganti rugi yang terdiri dari biaya, rugi dan bunga. Biaya adalah segala pengeluaran yang nyata-nyata telah dikeluarkan oleh debitur. Rugi adalah segala kerugian karena musnahnya atau rusaknya barang-barang milik kreditur akibat kelalaian debitur. Ganti kerugian yang dimaksud berupa kerugian material dan immaterial, biasanya kerugian tersebut diberikan dalam bentuk uang atau barang, namun ganti kerugian ini dapat pula diberikan dalam bentuk pemulihan keadaan sesuatu, bila ganti kerugian ini tidak dilaksanakan, maka dapat dituntut uang paksa/dwangsom walaupun uang paksa ini bukan bentuk ganti kerugian tetapi hanya sebagai penguatan agar ganti kerugian yang dimaksud dilaksanakan. Bunga adalah segala keuntungan yang diharapkan atau telah diperhitungkan.

Perbuatan melawan hukum sebagaimana diatur dalam Pasal 1365 KUH Perdata ini dapat pula digunakan sebagai dasar untuk mengajukan ganti kerugian atas perbuatan yang dianggap melawan hukum dalam proses transaksi bisnis secara online (E-Commerce), baik dilakukan melalui penyelesaian sengketa secara litigasi atau melalui pengadilan dengan mengajukan gugatan, maupun penyelesaian sengketa secara non litigasi atau di luar pengadilan misalnya dengan cara negosiasi, mediasi, konsiliasi atau arbitrase.

\section{Aspek Hukum Perbuatan Melawan Hukum dalam Transaksi Bisnis Secara Online (E-Commerce) Berdasarkan Burgerlijke Wetboek dan Undang-Undang ITE}

Perbuatan melawan hukum dalam transaksibisnissecaraonline (E-Commerce) dikatakan telah terjadi apabila telah terjadi (selesai) suatu perbuatan salah satu pihak yang sengaja dilakukan terhadap pihak lainnya dan akibat perbuatannya tersebut menimbulkan kerugian bagi pihak lainnya tersebut. Perbuatan mana dilakukan secara online atau di dunia maya melalui instrumen/data elektronik, baik menggunakan informasi atau dokumen elektronik dengan berbagai cara di dunia maya. Penggunaan data elektronik sebagai media penyampaian pesan/data sehingga dapat dilakukan pengiriman dan penerimaan informasi secara mudah dan ringkas, baik dalam bentuk data elektronik analog maupun digital, sesuai dengan pengertiannya bahwa E-commerce adalah sistem perdagangan yang menggunakan mekanisme elektronik yang ada di jaringan internet dan menjadi warna baru dalam dunia bisnis secara elektronik dan online.

Terjadinya perbuatan melawan hukum dalam transaksi bisnis secara online (E-Commerce) yang menimbulkan kerugian di atas, memerlukan aturan yang akan menjadi dasar hukum atas tuntutan ganti kerugiannya. Burgerlijke Wetboek dan Undang-Undang ITE memiliki peranan yang sangat penting dalam hal tersebut, karena secara eksplisit pengaturan tentang tuntutan ganti kerugian akibat perbuatan melawan hukum dalam transaksi bisnis secara online (E-Commerce) tidak diatur dalam peraturan perundang-undangan di 
Indonesia, namun sesuai amanat UndangUndang Kekuasaan Kehakiman, yang menyatakan bahwa hakim wajib menggali nilai-nilai yang hidup dalam masyarakat agar tidak terjadi kekosongan hukum, menjadi pegangan bahwa hakim tidak dapat menolak kasus apapun yang masuk ke pengadilan dengan alasan belum ada aturannya atau belum lengkap aturannya.

Penafsiran hukum secara ekstensif atau memperluas arti kata dalam suatu perundang-undangan menjadi salah satu cara untuk mengatasi masalah tersebut. Dengan demikian Pasal 1365 BW dapat dijadikan sebagai dasar hukum tuntutan ganti kerugian atas perbuatan melawan hukum dalam transaksi bisnis secara online (E-Commerce) ini, dengan dukungan pembuktian berdasarkan data elektronik yang diakui sebagai bukti yang sah seperti dalam hukum acara yang berlaku di Indonesia, telah diatur dalam Pasal 5 Undang-Undang ITE. Oleh karena itu, BW dan Undang-Undang ITE sangat berperan dalam menghadapi kendala terkait tuntutan ganti kerugian atas perbuatan melawan hukum dalam transaksi bisnis secara online (E-Commerce) termaksud.

\section{PENUTUP}

\section{Kesimpulan}

Berdasarkan analisis hukum yang telah dilakukan pada bab sebelumnya, dapat ditarik kesimpulan sebagai berikut:

a. Ketentuan hukum tentang perbuatan melawan hukum diatur dalam Pasal 1365 BW dan tidak diatur dalam Undang-Undang Nomor 11 Tahun 2008 Tentang Informasi dan Transaksi Elektronik. Ketentuan Pasal 1365 BW tersebut dapat diterapkan terhadap kasus perbuatan melawan hukum dalam transaksi bisnis secara online (E-Commerce), untuk mengisi kekosongan hukum, yang dilakukan berdasarkan penafsiran hukum secara ekstensif.

b. Munculnya kendala atas tuntutan ganti kerugian perbuatan melawan hukum dalam transaksi bisnis secara online (E-Commerce) dapat diselesaikan dengan membenahi perjanjian E-Commerce tersebut, harus memenuhi syarat sahnya perjanjian sebagaimana diatur dalam Pasal 1320 BW dan tidak melanggar ketertiban umum serta kesusilaan, juga harus diperhatikan aspek kehati-hatian saat membuat kesepakatan bisnis E-Commerce ini. Namun ganti kerugian yang timbul dari perbuatan melawan hukum dalam E-Commerce ini dapat dituntut, dengan memperhatikan hukum pembuktian atas kerugian yang timbul tersebut, baik secara materil maupun immaterial.

\section{Saran}

Adapun saran yang disampaikan Penulis adalah sebagai berikut:

a. Undang-Undang Nomor 11 Tahun 2008 Tentang Informasi dan Transaksi Elektronik perlu diubah atau ditambah atau diganti dengan peraturan terkait yang baru, yang mengakomodir beberapa ketentuan hukum terkait dengan Informasi dan Transaksi Elektronik, termasuk ketentuan mengenai perbuatan melawan hukum yang sering terjadi dalam transaksi bisnis secara online (E-Commerce). 
b. Perlunya sosialisasi peraturan perundang-undangan khususnya terkait masalah transaksi bisnis secara online agar masyarakat mengetahui aspek hukumnya.

\section{DAFTAR PUSTAKA}

Agus Raharjo, Cyber Crime Pemahaman dan Upaya Pencegahan Kejahatan Berteknologi, Citra Aditya Bakti, Bandung, 2002.

M. Arsyad Sanusi, Transaksi Bisnis dalam Electronic Commerce, Jurnal Hukum, Nomor 16 Vol 8, 2001.

Dikdik M. Arief Mansur dan Elisatris Gultom, Cyber Law Aspek Hukum Teknologi Informasi, PT Refika Aditama, Bandung, Mei 2005.

Edmon Makarim. Kompilasi Hukum Telematika, PT. Gravindo Persada, Jakarta, 2000.

Gunawan Widjaja \& Ahmad Yani. Hukum Tentang Perlindungan Konsumen, PT. Gramedia Pustaka Utama, Jakarta, 2000.

Jeffrey F. Rayport dan Bernard J. Jaworski, E-commerce, McGraw-Hill/Irwin, Singapura, 2001.

Mochtar Kusumaatmadja, Konsep-Konsep Hukum Dalam Pembangunan, Alumni. Bandung. 2002.
Munir Fuady, Teori Hukum Pembuktian (Pidana dan Perdata), Citra Aditya Bhakti, Jakarta, 2006.

Onno W. Purbo, Mengenai Electronic Commerce, PT Elex Media Komputindo, Jakarta 2001.

Riduan Syahrani, Seluk-Beluk Dan AsasAsas Hukum Perdata, Alumni, Bandung, 1992.

Subekti, Pokok-Pokok Hukum Perdata, Intermasa, Jakarta, 1979.

Aneka Perjanjian, Cetakan VII, Alumni, Bandung, 1985.

Wirjono Prodjodikoro, Asas-Asas Hukum Perjanjian, Cetakan VIII, Sumur Bandung, Jakarta, 1985. , Perbuatan Melanggar Hukum, Cetakan V, Sumur Bandung, Bandung, 1967.

Yee Fen Lim, Cyberspace Law, Commentaries and Materials, Oxford University Press, Victoria, 2006. 